\title{
Fish diversity studies of two rivers of the northeastern Godavari basin, India
}

\author{
Nilesh K. Heda \\ SAMVARDHAN (Society for the Conservation of Wetland Resources), Karanja (Lad), Washim, Maharashtra 444105, India \\ Email: nilheda@gmail.com
} Date of publication (online): 26 October 2009
Date of publication (print): 26 October 2009 ISSN $0974-7907$ (online) | 0974-7893 (print)

Editor: W. Vishwanath

\section{Manuscript details:}

Ms \# 01764

Received 23 April 2007

Final received 15 October 2009

Finally accepted 15 October 2009

Citation: Heda, N.K. (2009). Fish diversity studies of two rivers of the northeastern Godavar basin, India. Journal of Threatened Taxa 1(10): 514-518.

Copyright: (c) Nilesh K. Heda 2009. Creative Commons Attribution 3.0 Unported License. JoTT allows unrestricted use of this article in any medium for non-profit purposes, reproduction and distribution by providing adequate credit to the authors and the source of publication.

Author Details: Previously working in CES, IISc on People's Biodiversity Register project. PhD in fish ecology presently working as project leader on project grant provided by Rufford small grant foundation, UK. Closely working with fishermen and labours for the conservation of the riverine resources and livelihood issues through a non profit SAMVARDHAN.

Acknowledgments: Author is very much thankful to Prof. Madhav Gadgil and Dr. K.M. Kulkarni for necessary freedom and guidance. Discussion with Dr. Subramanian K.A. and Dr. Anuradha Bhat improved this work. Dr. Sanjay Kharat, Nilesh Dahanukar and Mukul Mahabaleshwarkar helped in the identification of the fishes. Thanks are also due to Mr. Tulsiram Dane and Mr. Subhash Bavane who helped me in the sampling of the fishes. Author is very much thankful to people of Mendha (Lekha) and Khursa villages of the Gadchiroli district for help during field survey. Author is thankful to Rufford Small Grant Foundation, UK and Sir Dorabaji Tata Trust, Mumbai for financial support.
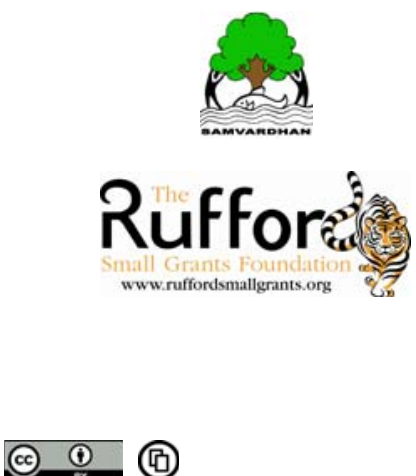

(ே)

OPEN AGGESS I FREE DOWNLOAD
Abstract: Fish diversity was explored in two rivers of the northeastern Godavari basin: the Adan, tributary of the Painganga, and the Kathani, tributary of the Wainganga. Both rivers are part of the same basin but present different ecological, climatic and anthropogenic settings. Six sites were sampled in each river system over three years using gill nets, cast nets and locally available nets; the 'catch per unit effort' criterion was used for sampling. Forty-seven species of fish were identified. Species richness (Jackknife 1 and rarefaction) and diversity measures (Shannon and Simpson) were calculated and their values clearly show that the Kathani is a more diverse ecosystem in terms of fish diversity than the Adan. This difference is mainly due to anthropogenic influences upon the Adan.

Keywords: Adan River, diversity indices, fish diversity, Godavari basin, Kathani River, species richness.

\section{INTRODUCTION}

Several ways of measuring the species diversity of biological communities have been described (MacArthur 1965; Whittaker 1970; Pielou 1975; Chao 1984; Magurran 1988, 2004, 2005; Krebs 1989; Chao \& Shen 2003), and this diversity is considered by ecologists to be an indicator of community well-being (Magurran 1988). India has considerable ichthyofaunal diversity. Day (1875) described 1,418 species of fish under 342 genera, and a century later Jayaram (1981) listed 742 freshwater species under 233 genera, 64 families and 16 orders from the Indian region. Talwar \& Jhingran (1991) estimated 930 species of fresh water fish belonging to 326 genera and 99 families. On a global scale, Indian fish populations represent $11 \%$ of species, $24 \%$ of genera and $57 \%$ of families (NBSAP India 2005). In the central Indian River systems (viz. Narmada, Godavari, Tapti and Krishna) Heda (2009) described 150 species belonging to 26 families. In spite of this rich diversity, literature concerning numerical studies of fish diversity is scarce. Bhat (2003) studied the diversity and ecology of four rivers in the Uttara Kannada District of Karnataka. Kar et al. (2006) studied diversity and the effect of environmental variables on fish of Sone Lake in Assam. The Godavari River, especially its northeastern part, is largely unexplored with regards to species inventory. In this study, an attempt was made to assess and compare the fish diversity of two rivers of the northeastern Godavari basin.

\section{STUdY AREA: (Fig. 1)}

The Godavari is the second largest river in India after the Ganga, and is often referred as the Vriddh (Old) Ganga or the Dakshin (South) Ganga. It rises near Nasik (Trunbakeshwar) in Maharashtra at an elevation of $1,067 \mathrm{~m}$ and flows for $1,465 \mathrm{~km}$ before emptying into the Bay of Bengal.

The first study river, the Kathani, is a tributary of the Wainganga and lies at $20^{\circ} 15^{\prime} .531^{\prime \prime} \mathrm{N} \& 80^{\circ} 31^{\prime} .196^{\prime \prime} \mathrm{E}-20^{\circ} 12^{\prime} .658^{\prime \prime} \mathrm{N} \& 79^{\circ} 59^{\prime} .620^{\prime \prime} \mathrm{E}$. It is an annual river originating in the Dhanora - Murumgaon hills at an altitude of $426.72 \mathrm{~m}$, and it flows west for $70 \mathrm{~km}$ before emptying into the Wainganga north of Gadchiroli $\left(20^{\circ} 10^{\prime} 21^{\prime \prime} \mathrm{N}\right.$ $\& 79^{\circ} 57^{\prime} 49^{\prime \prime} \mathrm{E}^{\prime}$ ). It is a mountain torrent river flowing through dry deciduous forest and runs dry in the summer, although water remains in some pools. The overall substratum type of the river is sandy with occasional rocks. The canopy is rich, with the dominant vegetation being bamboo (Dendrocalamus strictus), Ajan (Terminalia sp.) etc. The river flows through a sparsely inhabited area and no dams or significant industrial pollution were noted.

The second study river, the Adan, is a principal tributary of the Painganga and lies at $20^{\circ} 12^{\prime} 19.00^{\prime \prime} \mathrm{N}-77^{\circ} 10^{\prime} 01^{\prime \prime} \mathrm{E} \& 19^{\circ} 54^{\prime} 87.6^{\prime \prime} \mathrm{N}-78^{\circ} 12^{\prime} 61.4^{\prime \prime} \mathrm{E}$. The length of this river is $209.21 \mathrm{~km}$. It rises in the Washim District of Maharashtra and meanders north, east and south and meets the Painganga River. The river Arunavati unites with the Adan 


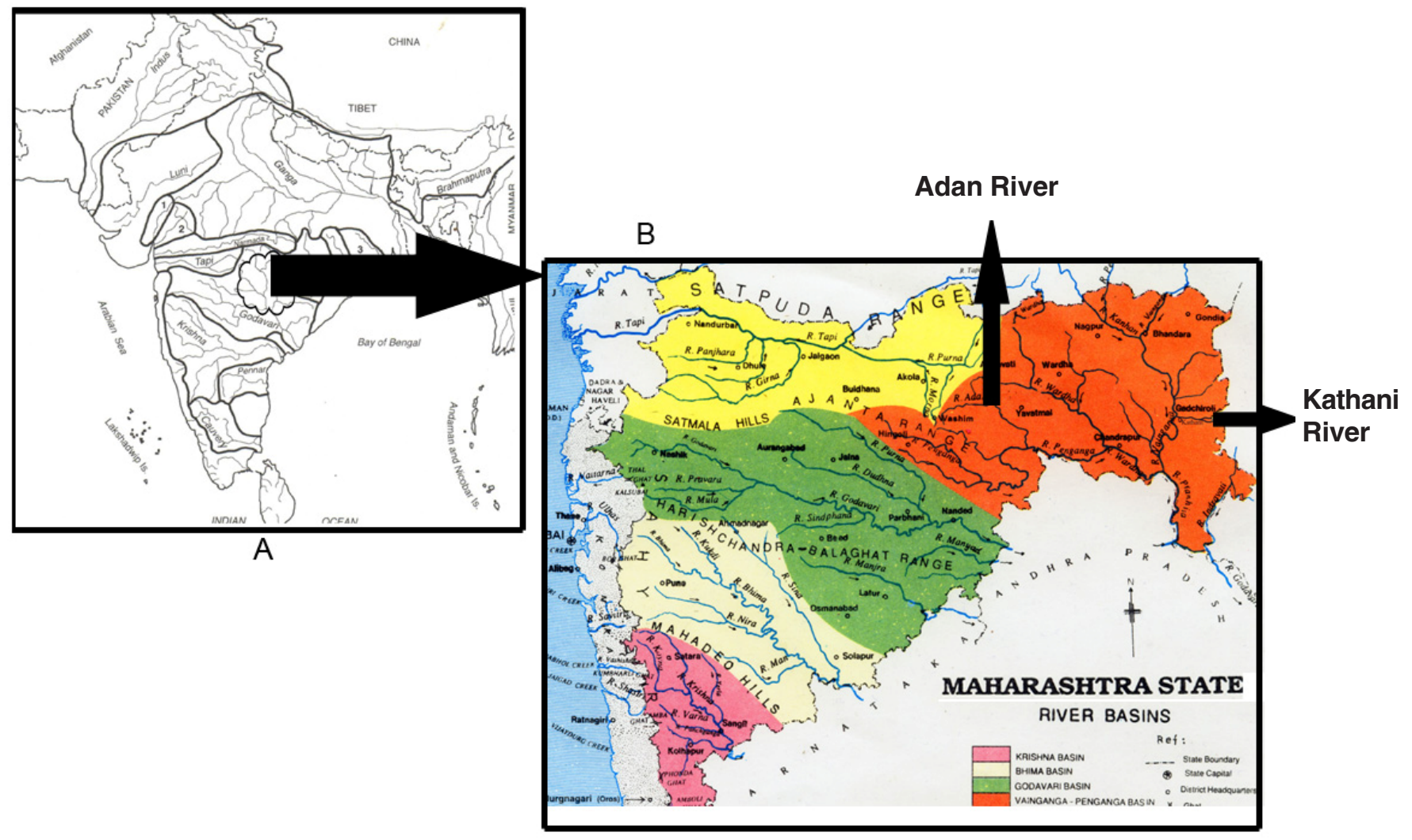

Figure 1. A - major drainages in India; B - study area

$13 \mathrm{~km}$ before it joins the Painganga. The valley of Adan is $10 \mathrm{~km}$ to $22 \mathrm{~km}$ wide. The river ceases to flow in summer, though some pools remain in the latter part of its course.

Two dams have been built on the Adan; one at the origin near Sonala village and the other near Karanja (Lad) city. The river flows through scrubland, degraded dry deciduous forest and areas with extensive agriculture (Table 1).

\section{Methods}

Sampling: Six sample points were chosen on each river in order to cover all areas, sample a range of habitat types (e.g. pools, rapids, falls) and assess the impact of human interventions (e.g. some sites were adjacent to villages, and on the Adan sites above and below the dam were sampled). Samples were collected seasonally from January 2003 to September 2005. For sampling cast nets, gill nets baited hooks and locally available nets were used. The same mesh size was used for all net samplings. Collected samples were preserved in $5 \%$ formalin solution in plastic bottles. Different bottles were maintained for different sampling sites and events. Preserved fish were identified in the laboratory via identification keys given by Day (1875), Talwar and Jhingran (1991), Jayaram (1999) and Daniels (2001). At each sampling point a $100 \mathrm{~m}$ long stretch was chosen which was sampled seasonally through 'random sampling' (Krebs, 1989, Magurran, 1988 , 2004). Cast netting was done without overlapping the previous casting.

Data analysis: It is not always possible to ensure that all sample sizes are equal, and the number of species invariably increases with sample size and sampling efforts. To cope with this problem I used the rarefaction technique of Sanders to
Table 1. Details of sampling sites

\begin{tabular}{|c|c|c|c|}
\hline River & Sampling point & Geographical coordinates & $\begin{array}{l}\text { Altitude } \\
\text { (m) }\end{array}$ \\
\hline \multirow[t]{6}{*}{ Adan } & Shivni bridge & $20^{\circ} 23^{\prime} 48.24 ” N \& 77^{\circ} 22^{\prime} 28.01 " \mathrm{E}$ & 416.00 \\
\hline & Injori bridge & 2024'22.22”'N \& 77030'10.33”E & 378.00 \\
\hline & Sangvi & $20^{\circ} 24^{\prime} 40.96 ” N \& 7^{\circ} 36^{\prime} 27.82^{\prime \prime} \mathrm{E}$ & 372.00 \\
\hline & Mankopra & $20^{\circ} 23$ '39.11"N \& 77040'00.46”E & 350.00 \\
\hline & Bori Arab & $20^{\circ} 20^{\prime} 59.89^{\prime \prime} \mathrm{N} \& 7^{\circ} 51^{\prime} 36.10^{\prime \prime} \mathrm{E}$ & 314.00 \\
\hline & Sangam - 2 & $19^{0} 54^{\prime} 80.83^{\prime \prime} \mathrm{N} \& 7^{0} 12^{\prime} 36.40^{\prime \prime} \mathrm{E}$ & 245.00 \\
\hline \multirow[t]{6}{*}{ Kathani } & Chavela & $20^{\circ} 15^{\prime} 90.12^{\prime \prime} \mathrm{N} \& 80^{\circ} 22^{\prime} 20.07^{\prime \prime} \mathrm{E}$ & 246.89 \\
\hline & Dhanora bridge & $20^{\circ} 17^{\prime} 30.23$ ”N \& 8019'26.77”E & 237.74 \\
\hline & Wadadin & $20^{\circ} 14^{\prime} 37.80^{\prime \prime} \mathrm{N} \& 80^{\circ} 15^{\prime} 59.15^{\prime \prime} \mathrm{E}$ & 225.55 \\
\hline & Dev Doh & $20^{\circ} 13^{\prime} 40.67 " \mathrm{~N} \& 80^{\circ} 09^{\prime} 54.27 " \mathrm{E}$ & 209.85 \\
\hline & Bamni village & $20^{\circ} 13^{\prime} 02.66^{\prime \prime} \mathrm{N} \& 8^{\circ} 05^{\prime} 35.21^{\prime \prime} \mathrm{E}$ & 205.74 \\
\hline & Sangam - 1 & 2012'39.87"N \& 79059'35.01"E & 195.99 \\
\hline
\end{tabular}

calculate the number of species expected in each sample if all samples were of a standard size (Magurran 1988; Bruce et al. 1998; Bhat 2002, 2003, 2004). The Jackknife-1 measure was used to calculate species richness based on the observed frequency of rare or unique species in the community. One problem associated with diversity measurement is determining what sample size to adopt. A practical approach to this problem is to use the concept of the species accumulation curve (Butler \& Chazdon 1998), which gives an idea about the extent of sampling efficiency and rate of increase in the number of species per the effort (Christen \& Nakamura 2000; Dahanukar et al. 2004; John et al. 2004; Mao et al. 2005). Two diversity measures were used to calculate the alpha diversity (i.e. within site or within sample diversity), the Shannon diversity index (H') and Simpson's index (Krebs 1989). EstimateS (Colwell 1997) and Biodiversity Pro (McAleece et al. 2006) software was used for calculations of richness estimates, diversity indices 


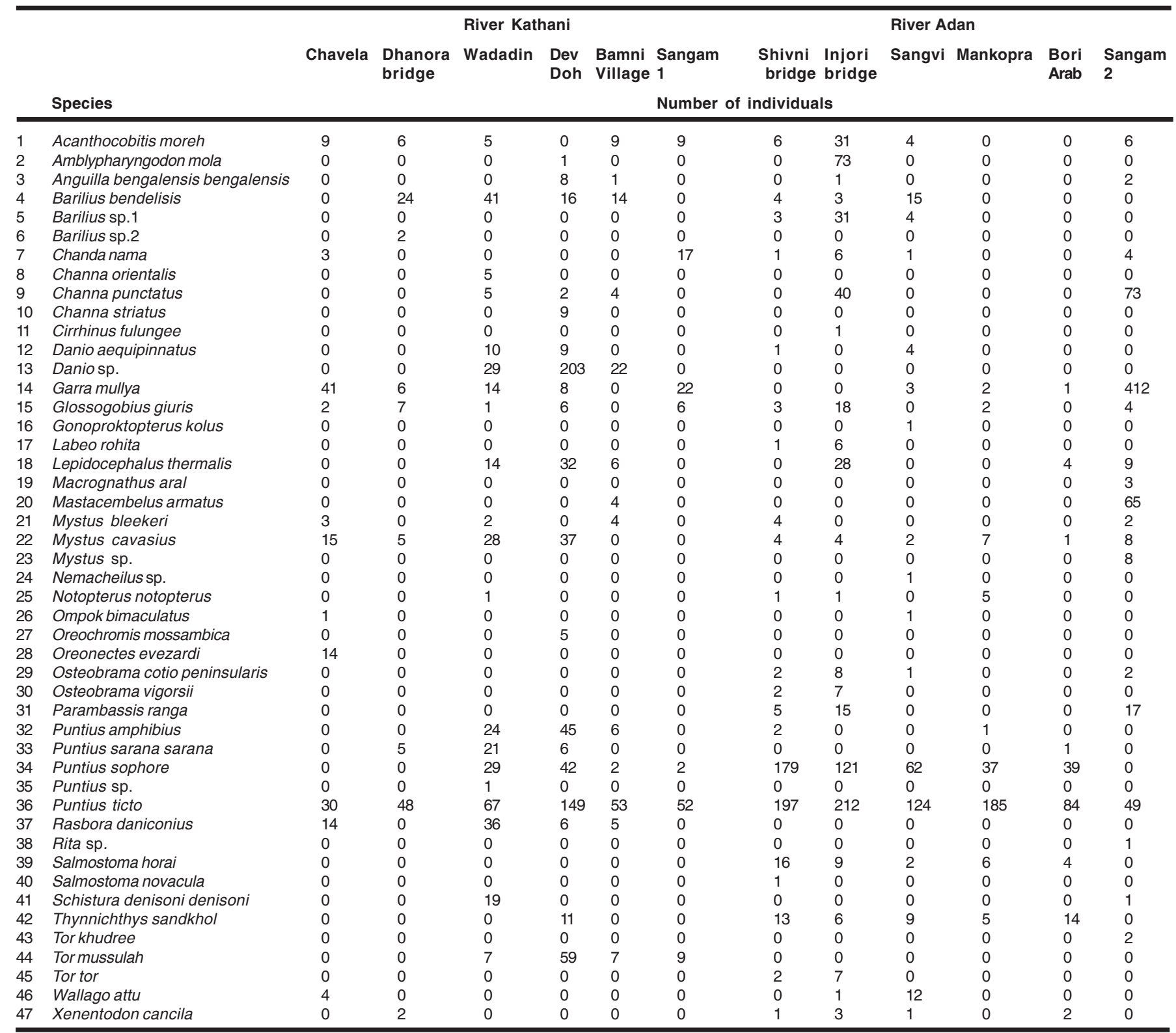

and similarity measures.

\section{Results}

3894 individuals were collected from both rivers (1508 from the Kathani and 2386 from the Adan). A total of 47 species were identified (32 Kathani, 38 Adan). Cypriniformes were the dominant group in both rivers (15 species), with dominant species from both rivers being Puntius ticto. The singletons (with only one individual) at Kathani are Amblypharyngodon mola, Puntius sps., Notopterus notopterus and Ompok bimaculatus. The singletons from Adan are Nemacheilus sp., Rita sp., Gonoproktopterus kolus, Labeo fulungee, Schistura denisoni denisoni, Ompok bimaculatus, Tor sp., Puntius sarana sarana, Salmostoma novacula and Tor khudree. Puntius ticto is widely distributed and reported from all 12 sampling points, while 15 species were reported from only one sampling point. Cyprinidae is the most species rich family in both the rivers with 28 species, whereas 10 families were represented by only one species (Fig 2) (Table 2).

Species richness:

Species richness of both rivers combined: Jackknife 1 measure of species richness showed 56 species, which can be considered an upper bound for the species richness of both rivers combined. Species richness calculated by rarefaction gives 47 species, which is considered the lower bound. Thus I conclude that combining both rivers, number of species ranges from 47 to 56 .

Species richness measures calculated for 1508 individuals for river Kathani and 2,386 individuals for Adan. Kathani shows 38 species (Jackknife 1 with SD 2.19) while Adan show 40 (Jackknife 1 with SD 3.32) species. The rarefaction of the two rivers show Adan 34 species and Kathani 32 species at 1501 individuals.

Mann-Whitney U test (Brower et al. 1990) was performed 


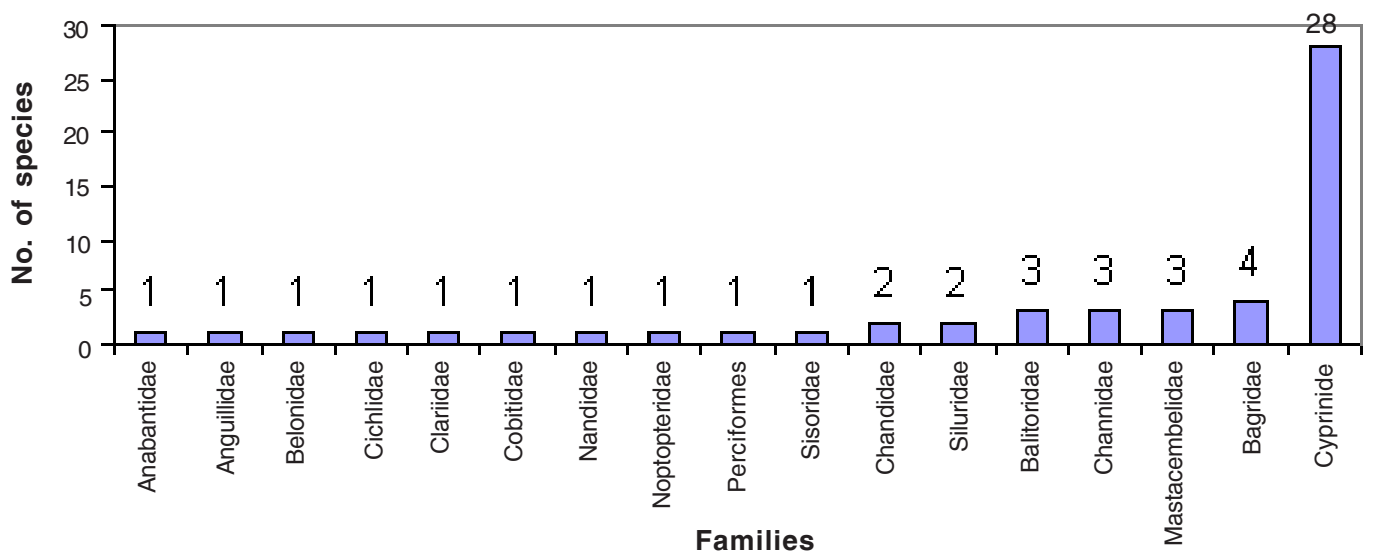

Figure 2. Number of fish species in different families (Both rivers combined)

Table 3. Values of species richness, diversity indices for Adan and Kathani

\begin{tabular}{llll}
\hline & Attributes & Adan & Kathani \\
\hline 1 & Samples & 111 & 143 \\
2 & Individuals (computed) & 2386 & 1508 \\
3 & Species richness: Jack 1 Mean & 47.91 & 36.97 \\
4 & Jack 1 SD (analytical) & 3.32 & 2.19 \\
5 & Rarefied species richness at 1501 individuals & 34.13 & 31.98 \\
6 & Shannon mean & 2.1 & 2.58 \\
7 & Shannon SD (runs) & 0.19 & 0.13 \\
8 & Simpson mean & 4.8 & 8.34 \\
9 & Simpson SD (runs) & 0.99 & 1.13 \\
\hline
\end{tabular}

to find out differences in the species richness values. The null hypothesis $\left(\mathrm{H}_{0}\right)$ put was 'there is no significant difference between the species richness values of both rivers'. Null hypothesis was rejected as significant difference was detected in both rivers species richness for Jackknife 1 ( $\mathrm{U}=3413.5, \mathrm{P}<$ $0.0001, \mathrm{CI}=6.77-9.38)$. However, the rarefied species richness shows no significant difference between the values at similar number of individuals $(\mathrm{U}=12685, \mathrm{P}=0.0905, \mathrm{CI}=-1.56-$ 0.12). That means at similar number of the individuals both rivers do not show significant differences in the species richness values.

\section{Species diversity}

The Shannon index for the Kathani was 2.58, and for the Adan 2.1 (calculated using natural log). The Mann-Whitney $\mathrm{U}$ test showed a highly significant difference between rivers $(\mathrm{U}=111, \mathrm{P}<0.0001)$, with the Kathani being more diverse than the Adan. The mean value of the Simpson diversity index for the Adan is 4.8, for the Kathani 8.34 ( $\mathrm{U}=24, \mathrm{P}<0.0001$ with $\mathrm{CI}=2.98$-3.23) which again confirms that both rivers are differs in their diversity values (Table 3 ).

\section{Discussion}

Although both rivers are the part of same larger basin, significant differences in diversity values were observed. The Kathani is a small river in comparison to the Adan but shows higher diversity. The difference in the value of the diversity indices and species richness values can be explained by considering anthropogenic factors that include pollution (much less in the Kathani) and damming (the Adan has 2 dams). This study supports earlier studies performed by Dean et al. (1998) on the effect of human induced influences on the diversity of the fish in three small streams in southern Ontario and studies by Habit et al. (2006). Dale et al. (1999) found that an overall decrease in fish abundance occurs with increase in the length of non-forested riparian zones (a situation that can be observed in the Adan) while several studies have demonstrated that dams lower fish species diversity (Michio et al. 2007; Morita \& Yamamoto 2002) (Table 4).

\section{References}

Bhat, A. (2002). A study of the diversity and ecology of the fresh water fishes of four river systems of Uttar Kannada District, Karnataka, India. PhD. Thesis. Center for ecological sciences, Indian Institute of Science, Bangalore.

Bhat, A. (2003). Diversity and composition of freshwater fishes in river systems of Central Western Ghats, India. Environmental Biology of Fishes 68(1): 25-38.

Bhat, A. (2004). Patterns in the distribution of freshwater fishes in rivers of Central Western Ghats, India and their associations with environmental gradients. Hydrobiologia 529: 83-97.

Brower, J., J. Zar \& C.V. Ende (1990). Field and Laboratory Methods for General Ecology ( $3^{\text {rd }}$ Edition). Wm.C. Brown Publishers, 237pp.

Bruce, E.Y., D. Tmderbra \& V.N. George (1998). Diversity and conservation of understory birds in the Tiler in mountains, Costarica. The Auk 115(4):998-1016.

Butler, J.B. \& R.L. Chazdon (1998). Species richness, spatial variation and abundance of the soil seed bank of a secondary tropical rain forest. Biotropica 30(2): 214-222.

Chao, A. (1984). Non-parametric estimation of the number of classes in a population. Scandinavian Journal of Statistics 11: 265-270.

Chao, A. \& T.J. Shen (2003). Non-parametric estimation of Shannon's index of diversity when there are unseen species in sample. Journal of Environmental and Ecological Statistics 10: 429 - 443.

Christen, J.A. \& M. Nakamura (2000). On the analysis of accumulation curves. Biometrics 56(3): 754 .

Colwell, R.K. (1997). EstimateS: Statistical estimation of species richness and shared species from samples. Version 7.5. User's Guide and application published at http://viceroy.eeb.uconn.edu/estimates.

Dahanukar, N., R. Raut \& A. Bhat (2004). Distribution, endemism and threat status of freshwater fishes in the Western Ghats of India. Journal of Biogeography 31:123-136.

Dale, J.E.B., G. Helfman, J.O. Harper \& P.V. Bolstad (1999). Effects of Riparian Forest Removal on Fish Assemblages in Southern Appalachian Streams. Conservation Biology 13(6): 1454-1465.

Daniels, R. (2001). Fresh Water Fishes of Peninsular India. University press, $282 \mathrm{pp}$.

Day, F. (1875). The Fishes of India: Being A Natural History of the Fishes 
Table 4. Comparison of land use pattern and anthropogenic factors for Adan and Kathani rivers.

\begin{tabular}{|c|c|c|c|}
\hline \multirow[t]{2}{*}{ Attributes } & \multicolumn{2}{|c|}{ River Adan } & \multirow{2}{*}{$\begin{array}{l}\text { River Kathani } \\
\text { Gadchiroli District }\end{array}$} \\
\hline & Washim District & Yeotmal District & \\
\hline Forest cover of District from which river flows & $6.46 \%$ & $18.77 \%$ & $69.78 \%$ \\
\hline Forest area of Districts from which river flows & $8.72 \%$ & $27.35 \%$ & $90.96 \%$ \\
\hline Population Density of District from which river flows (2002): $\mathrm{km}^{-1}$ & 300 & 181 & 67 \\
\hline 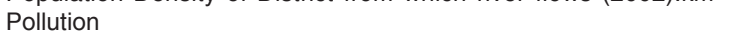 & \multicolumn{2}{|c|}{ Moderate } & Negligible \\
\hline Use of pesticides in the adjacent farms & \multicolumn{2}{|c|}{ Substantial } & Negligible \\
\hline
\end{tabular}

Known to Inhabit The Seas and Fresh Waters of India, Burma and Ceylon. Text and Atlas in 4 Parts. London, $\mathrm{xx}+778: 195 \mathrm{pp}$.

Dean, G.F., E.D. Kott, P.L. Roman \& D. George (1998). A quarter century of change in the fish communities of three small streams modified by anthropogenic activities. Journal of Aquatic Ecosystem Stress and Recovery 6(2): 111-127.

Habit, E., M.C. Belk, R.C. Tuckfield \& P. Oscar (2006). Response of the fish community to human-induced changes in the Biobýo River in Chile. Freshwater Biology 51: 1-11.

Heda, N.K. (2009). Freshwater Fishes of Central India: A Field Guide. (2009). Vigyan Prasar, Department of Science and Technology, Government of India, Noida, 169pp.

Jayaram, K.C. (1981). The Freshwater Fishes of India, Pakistan, Bangladesh, Burma and Sri Lanka - A Handbook. Zoological Survey of India, Calcutta, xxii $+475 \mathrm{pp}$.

Jayaram, K.C. (1999). The Fresh Water Fishes of The Indian Region. Narendra Publishing House, New Delhi, $551 \mathrm{pp}$.

John, S.G., I.U. Karl \& L. John (2004). On species accumulation and species area curves. Global Ecology E Biogeography 13(6): 567.

Kar, D., A.V. Nagarathna \& T.V. Ramachandra (2006). Fish Diversity and Conservation aspect in an aquatic ecosystem in India. Paper published at http://wgbis.ces.iisc.ernet.in/energy/water/paper/ fishdiversity/fishdiversity.html.

Krebs, C.J. (1989). Ecological Methodology. Harper and Row publisher, New York, 645pp.

MacArthur, R.H. (1965). Patterns of Species Diversity. In: Patric, R (ed.). Benchmark Papers in Ecology 13. Hutchinson Ross Publishing Company, Pennsylvania, 14pp.

Magurran, A.E. (1988). Ecological Diversity and its Measurement. Princeton University Press, Princeton, NJ, 179pp.
Magurran, A.E. (2004). Measuring Biological Diversity. Blackwell Publishing, 248pp.

Magurran, A.E. (2005). Species abundance distributions: pattern or process? Functional Ecology 19: 177-181.

Mao, C.X., R.K. Colwell \& J. Chang (2005). Estimating the Species Accumulation Curve Using Mixtures. Biometrics 61(2): 433-441.

McAleece, N., P.J.D. Lambshead \& G.L.J. Paterson (2006). Biodiversity Pro. Software, which calculate wide array of species richness, diversity and similarity indices. Downloaded from http://www.sams.ac.uk/ activities/downloads/html

Michio, F., S. Kameyama, M. Kaneko, K. Nakao \& F.S. Ashley (2007). Modelling the effects of dams on freshwater fish distributions in Hokkaido, Japan. Freshwater Biology 52(8): 1511-1524

Morita, K. \& S. Yamamoto (2002). Effects of Habitat Fragmentation by Damming on the Persistence of Stream-Dwelling Charr Populations. Conservation Biology 16(5): 1318-1323

NBSAP India (2005). Third National Report. Available at: http:// www.biodiv.org/doc/world/in/in-nr-03-en.pdf)

Pielou, E.C. (1975). Ecological Diversity. Wiley interscience publication, New York, 163pp.

Talwar, P.K. \& A.G. Jhingran (1991). Inland Fishes of India and Adjacent Countries (Vol. I \& II). Oxford \& IBH Pub. New Delhi, 1097pp.

Whittaker, R.H. (1970). Communities and Ecosystems. The Macmillan Company, USA, $157 \mathrm{pp}$. 